\title{
Management of Barley Seedling Disease Caused by Sclerotium rolfsii Through Soil Amendment with Tricho-Compost
}

\author{
Md. Iqbal Faruk \\ Plant Pathology Division, Bangladesh Agricultural Research_Institute, Joydebpur, Bangladesh \\ Email address: \\ mifaruk2012@yahoo.com \\ To cite this article: \\ Md. Iqbal Faruk. Management of Barley Seedling Disease Caused by Sclerotium rolfsii Through Soil Amendment with Tricho-Compost. \\ European Journal of Biophysics. Vol. 7, No. 1, 2019, pp. 1-7. doi: 10.11648/j.ejb.20190701.11
}

Received: February 13, 2019; Accepted: March 28, 2019; Published: May 23, 2019

\begin{abstract}
The efficacy of formulated Trichoderma harzianum based Tricho-compost, seed treatment with Trichoderma spore suspension Trichoderma inocula and chemical fungicide Provax 200 WP were tested against seedling disease of barley caused by soil borne pathogen Sclerotium rolfsii in the research field of Plant Pathology Division, Bangladesh Agricultural Research Institute (BARI), Gazipur, Bangladesh during 2013-14, 2014-15 and 2015-16. Tricho-composts were prepared with mixed substrates of cow dung, rice bran and poultry refuse colonized by $T$. harzianum. The results exhibited that seedling mortality of barley was significantly reduced by the Tricho-compost, Trichoderma inocula and Provax 200 WP in all the years. The yield of barley was sharply increased over control due to the T. harzianum formulations and Provax 200 WP. Among the treatments, application of Tricho-compost was found more efficient in the reduction of seedling mortality and acceleration of plant growth with increased yield of barley under $S$. rolfsii inoculated field experiments in Bangladesh. Seed treatment with Provax $200 \mathrm{WP}$ and Trichoderma inocula also showed promising in reduction of seedling mortality and increasing plant growth and yield of barley.
\end{abstract}

Keywords: Barley, Provax 200 WP, Sclerotium roflsii, Seedling Disease, Tricho-Compost, Trichoderma Inocula

\section{Introduction}

Barley (Hordeum vulgare L.) is a cereal crop of international importance and stands fourth major food grain crop after wheat, rice, and maize in the world in both quantity produced (136 million tons) and area of cultivation $\left(566,000 \mathrm{~km}^{2}\right)$ [1-2]. It is a major source of food for large number of people living in the cooler semi-arid areas of the world. The crop is being used as food, animal feed and industrial raw material in food and beverages industry. However, the crop suffers significant yield losses from a biotic and biotic stresses in the world [3]. The crop can be grown in drought prone areas as well as saline areas of Bangladesh. The yield per unit area of barley at present is low in Bangladesh compared to other country.

There are many biotic and a biotic factors responsible for low yield of barley in Bangladesh. Among the factors, diseases play an important role. At least 17 important diseases of the crop have been recorded in the country [4-5] where seedling disease caused by Sclerotium rolfsii is one of the major one. Sclerotium rolfsii, an omnivorous, soilborne fungal pathogen, causes disease on a wide range of agricultural and horticultural crops and difficult to control through conventional method such as cultural, physical, chemical etc. Chemical control of this fungus using fungicides required large amount of chemical which causes health hazardous to grower and pollution of environment and soil. Thus, biological control using antagonistic microbes alone, or as a supplement of the minimizing of chemical pesticides in the integrated plant disease management system, has become more important and alternative methods for management of disease of many crops especially disease caused by soil borne pathogens [68]. Many studies have been shown that biological control is an environmentally friendly alternative method for soilborne pathogens [9-10]. Various fungal species have been used as biological control agents that effectively control plant diseases. Different species of Trichoderma such as $T$. 
harzianum, T. virens, T. viride, which occupied about $90 \%$ of such bio-control agents, are the most potent antagonistic fungi against the soil borne pathogens and have been used many developed countries in the world [11-12]. The antagonistic activity of $T$. harzianum for the management of various plant diseases including seedling diseases caused by several plant pathogenic fungi viz. S. rolfsii, $F$. oxysporum etc. have been reported by many investigators [13-17]. Trichoderma spp. have been reported to compete for nutrients and space, secrete antifungal compounds, parasitize fungal pathogens, and induce systemic resistance in the host plant [18-19]. Singh et al. [20] reported that mass production of Trichoderma on solid substrates promotes the synthesis of the desired enzymes which help its bio-control mechanism. So, the utilization of large number of low cost agro-wastes and organic materials as substrates for potential higher volumetric productivity are necessary to promote the Trichoderma. Many studies shown that different substrates viz. wheat bran, rice bran, maize bran, sawdust, rice straw, chickpea bran, grass pea bran, rice course powder, black gram bran, cow dung, poultry manure, ground nut shell, black ash, coir waste, spent straw from mushroom bed, talc, vermiculite sewage sludge compost are cost effective for mass multiplication of Trichoderma [21-23].

In Bangladesh the potentials of $T$. harzianum spore suspension as a seed treating agent and soil amendments with the compost materials colonized by $T$. harzianum under field condition have not yet been fully explored. Therefore, the present study was undertaken to find out a suitability of solid substrate for mass production T. harzianum in compost materials called Tricho-compost and also its spore suspension for seed treatment to reduce seedling disease caused by $S$. rolfsii Sacc. of barley.

\section{Materials and Methods}

The efficacy of Trichoderma harzianum spore suspension called Trichoderma inocula, Tricho-composts and Provax 200 WP against seedling disease of barley caused by Sclerotium rolfsii was investigated in the field of Plant Pathology Division, BARI, Gazipur at three cropping seasons during 2013-14, 2014-15 and 2015-16. Previously, seventy two isolates of T. harzianum were collected and isolated from different location of Bangladesh and their efficacy was tested against different soil borne pathogens including $S$. rolfsii in the laboratory. Few isolates of T. harzianum including TKC3 were found more vigorous against borne pathogens including $S$. rolfsii. A pure culture of T. harzianum (TKC3) was grown in potato dextrose agar (PDA) medium which was used to formulate in the substrates.

\subsection{Tricho-Compost Preparation}

Isolated T. harzianum (TKC3) was initially formulated on substrates containing a mixture of rice bran, wheat bran and mustard oilcake. The formulated T. harzianum was further mass multiplication by colonized $T$. harzianum in two different mixtures of cow dung based compost materials. One of those composts contained mixture cow dung and rice bran (@) 2: 1) designated as Trico-compost-1 and the other contained a mixture of cow dung, rice bran and poultry manure (@2: 1: 1) designated as Trico-compost-2. The formulated Trichoderma was added in between two layers of compost materials and kept for 45-50 days with maintaining the moisture content approximately $60-70 \%$ for rapid colonized compost materials by $T$. harzianum under room temperature $\left(27 \pm 2^{\circ} \mathrm{C}\right)$. The spore concentrations of the Tricho-composts were determined by dilution plate method which was approximately $1 \times 10^{7}$ to $1 \times 10^{8}$. Analyses of chemical compositions of Tricho-composts show that contained as much as $20 \%$ organic carbon and considerable amount of 11 different nutrient elements viz. N-1.25\%, P$0.63 \%, \mathrm{~K}-0.73 \%$, S- $0.23 \%$ ), Ca- $1.68 \%$, Mg- $0.43 \%$, B- $0.01 \%$, $\mathrm{Cu}-0.01 \%$, Fe-0.11\%, Mn-0.022\%, and Zn-0.026\%.

\subsection{S. rolfsii Inocula Preparation}

Fungal strain of $S$. rolfsii was collected and isolated from infected plant of barley. The pure culture of $S$. rolfsii was prepared on PDA medium. The inoculum of $S$. rolfsii was multiplied separately on a mixture of wheat bran, grass pea bran and mustard oilcake (MOC).

\subsection{Seed Treatment}

The T. harzianum was cultured in PDA and potato dextrose broth (PDB) media and the spores were harvested from 10 days old culture separately. The seeds of barley (var. BARI Barley-2) were treated with the spore suspension of $T$. harzianum maintaining the approximate spore concentration of $1 \times 10^{8} / \mathrm{ml}$. Similarly another set of seeds were also treated with Provax 200 WP (Carboxin + Thiram 37.5\%WS) @ 2.5 $\mathrm{g} / \mathrm{kg}$ seeds at the time of seed sowing.

\subsection{Field Experiment}

The experiment was conducted in the field of Plant Pathology Division, BARI, Gazipur during 2013-14, 2014-15 and 2015-16 cropping years. There were six treatments viz. (i) seed treatment with Provax $200 \mathrm{WP}$ (ii) seed treatment with Trichoderma spore suspension-1 (spores were harvested from PDA culture and spore concentration approx. 1 X10 $/ \mathrm{ml}$ ) (iii) seed treatment with Trichoderma spore suspension-2 (spores were harvested from PDB culture spore concentration approx. $1 \times 10^{8} / \mathrm{ml}$ ) (iv) soil amendment with Trichocompost-1 (v) soil amendment with Tricho-compost-2 and (vi) untreated control. The experiment was laid out in randomized complete block design (RCBD) with 3 replications. The unit plot size was $2.5 \mathrm{~m} \times 2 \mathrm{~m}$. The field soil was inoculated with $S$. rolfsii colonized substrate consisting of grass pea bran, wheat bran and mustard oilcake (a) $100 \mathrm{~g} / \mathrm{m}^{2}$ of soil and allowed the pathogen establishment in the soil for 10 days. Then the soil was treated again by Tricho-compost @3t/ha and kept for 7 days for Trichoderma establishment. The seeds of barley var. BARI Barley-2 were sown@100 kg ha ${ }^{-1}$ in the experimental plots with 
maintaining row to row distance of $20 \mathrm{~cm}$. Proper intercultural operations were done for better growth of barley in the field. No plant protecting chemicals (insecticides or fungicides) were applied in the field.

\subsection{Determination of Seedling Disease}

The experimental plots were inspected routinely to observe the disease of plant based on the symptom appears in seedlings. In case of complexity to identify the disease, symptoms-bearing plants were collected from the field using polythene bag and brought to the Plant Pathology Laboratory, BARI. From the infected plants, the fungi were isolated following tissue planting methods [24]. After incubation, the fungi that grew over PDA were purified by the hyphal tip culture method. The isolated fungi were identified as $S$. rolfsii according to reference mycology books and manuals [25-26].

\subsection{Data Collection and Analysis}

Data on different parameters viz. seedling mortality, shoot height, shoot weight, root length, root weight and yield of barley were taken. Seedling disease incidence data was started at the time of disease appeared and it was continuing until 40 days of seed sowing. Plant growth parameters shoot height, shoot weight, root length, root weight were recorded 35-40 days after seed sowing. The percent data were converted into arcsine transformation values before statistical analysis. Data were analyzed statistically by using the MSTATC program. The treatment effects were compared by applying the least significant different (LSD) test at $\mathrm{P}=0.05$ level.

\section{Results}

The efficacy of T. harzianum used as seed treatment by its spore suspension (Trichoderma inocula) and its mass production in compost materials called Tricho-composts for the management of seedling disease of barley caused by soil borne pathogen $S$. rolfsii as well as yield of barley was tested in field experiments during the period from 2012-13 to 201516.

\subsection{Effect of Tricho-Compost, Trichoderma Inocula and Provax on the Shoot Height and Shoot Weight of Barley in the Field}

Application of formulated T. harzianum, Tricho-compost in the soil, and seed treatment with Trichoderma inocula and provax were significantly enhanced the growth of barley in all the years (Table 1). In 2013-14 cropping year, all the treatments gave significantly higher shoot height then untreated control (Table 1). During 2014-15 cropping year, soil amendment with $T$. harzianum based Trichocomposts (Tricho-compost-1 and 2) gave the higher shoot height followed by seed treatment with Provax 200 WP and Trichoderma inocula. More or less similar trend was also observed during 2015-16 cropping year. The lowest shoot height was recorded from untreated control in all the years (Table 1). In the case of shoot weight the highest shoot weight was recorded due to soil amendment with Trichocompost-2 followed by Tricho-compost-1, seed treatment with Provax $200 \mathrm{WP}$ and T. harzianum inocula and the lowest shoot weight was recorded from untreated control during 2013-14 cropping year (Table 2). During 2014-15 and 2015-16 cropping years soil amendment with $T$. harzianum based Tricho-composts (Tricho-compost-1 and 2) gave the higher shoot weight followed by seed treatment with Provax 200 WP and T. harzianum inocula and the lowest shoot weight was recorded from untreated control (Table 1).

Table 1. Effect of T. harzianum on shoot growth of barley under Sclerotium rolfsii inoculated field soils during three consecutive years.

\begin{tabular}{|c|c|c|c|c|c|c|}
\hline \multirow[t]{2}{*}{ Treatments } & \multicolumn{3}{|c|}{$\begin{array}{l}\text { Shoot height of barley during three consecutive } \\
\text { years }(\mathrm{cm})\end{array}$} & \multicolumn{3}{|c|}{$\begin{array}{l}\text { Shoot weight of barley during three consecutive } \\
\text { years }\left(\text { gplant }^{-1}\right)\end{array}$} \\
\hline & 2013-14 & 2014-15 & 2015-16 & 2013-14 & 2014-15 & 2015-16 \\
\hline Seed treatment with Provax & $60.93 \mathrm{a}$ & $62.37 \mathrm{~b}$ & $64.17 \mathrm{~b}$ & $7.07 \mathrm{ab}$ & $11.60 \mathrm{~b}$ & $17.67 \mathrm{~b}$ \\
\hline Seed treatment with Trichoderma inocula-1 & $61.60 \mathrm{a}$ & $65.43 \mathrm{~b}$ & $63.57 \mathrm{~b}$ & $6.73 \mathrm{ab}$ & $11.67 \mathrm{~b}$ & $16.53 \mathrm{~b}$ \\
\hline Seed treatment with Trichoderma inocula- 2 & $59.60 \mathrm{a}$ & $64.37 \mathrm{~b}$ & $63.70 \mathrm{~b}$ & $6.40 \mathrm{~b}$ & $11.47 \mathrm{~b}$ & $17.20 \mathrm{~b}$ \\
\hline Soil amendment with Tricho-compost-1 & $62.73 \mathrm{a}$ & $74.77 \mathrm{a}$ & $71.67 \mathrm{a}$ & $7.80 \mathrm{ab}$ & $18.53 \mathrm{a}$ & $23.07 \mathrm{a}$ \\
\hline Untreated Control & $47.60 \mathrm{~b}$ & $50.85 \mathrm{c}$ & $48.97 \mathrm{c}$ & $4.87 \mathrm{c}$ & $7.23 \mathrm{c}$ & $12.67 \mathrm{c}$ \\
\hline
\end{tabular}

Values in a column having same letter did not differ significantly $(\mathrm{P}=0.05)$ by LSD.

\subsection{Effect of Tricho-Compost, Trichoderma Inocula and Provax on the Root Growth and Root Weight of Barley}

Soil amendment and seed treatment with different formulation of $T$. harzianum and seed treatment with Provax 200 WP were significantly increased the root length and root weight of barley as compared to untreated control plots during 2013-14, 2014-15 and 2015-16 cropping years (Table
2). Among the treatments, soil amendments with Trichocomposts (Tricho-compost-1 and 2) were found to be the better for enhancing root length and root weights of barley compared to the rest of the treatments. Besides, minimum root length and root weight of barley was observed in untreated control during three years. 
Table 2. Effect of T. harzianum on root growth of barley under Sclerotium rolfsii inoculated field soils during three consecutive years.

\begin{tabular}{lllllll}
\hline \multirow{2}{*}{ Treatments } & \multicolumn{2}{l}{$\begin{array}{l}\text { Barley root length during three consecutive } \\
\text { years }(\mathbf{c m})\end{array}$} & \multicolumn{3}{l}{$\begin{array}{l}\text { Barley root weight during three consecutive } \\
\text { years }\left(\text { gplant }^{-1} \text { ) }\right.\end{array}$} \\
\cline { 2 - 7 } & $\mathbf{2 0 1 3 - 1 4}$ & $\mathbf{2 0 1 4 - 1 5}$ & $\mathbf{2 0 1 5 - 1 6}$ & $\mathbf{2 0 1 3 - 1 4}$ & $\mathbf{2 0 1 4 - 1 5}$ & $\mathbf{2 0 1 5 - 1 6}$ \\
\hline Seed treatment with Provax & $9.47 \mathrm{ab}$ & $7.50 \mathrm{c}$ & $7.90 \mathrm{~b}$ & $1.27 \mathrm{ab}$ & $2.36 \mathrm{~b}$ & $3.53 \mathrm{~b}$ \\
Seed treatment with Trichoderma inocula-1 & $9.20 \mathrm{ab}$ & $8.10 \mathrm{c}$ & $7.93 \mathrm{~b}$ & $1.00 \mathrm{ab}$ & $2.20 \mathrm{~b}$ & $3.40 \mathrm{~b}$ \\
Seed treatment with Trichoderma inocula-2 & $10.40 \mathrm{ab}$ & $8.01 \mathrm{c}$ & $8.64 \mathrm{~b}$ & $0.97 \mathrm{ab}$ & $1.93 \mathrm{~b}$ & $2.90 \mathrm{c}$ \\
Soil amendment with Tricho-compost-1 & $10.47 \mathrm{ab}$ & $9.23 \mathrm{~b}$ & $12.23 \mathrm{a}$ & $1.17 \mathrm{ab}$ & $2.42 \mathrm{~b}$ & $4.37 \mathrm{a}$ \\
Soil amendment with Tricho-compost-2 & $12.67 \mathrm{a}$ & $10.25 \mathrm{a}$ & $12.53 \mathrm{a}$ & $1.40 \mathrm{a}$ & $3.17 \mathrm{a}$ & $4.47 \mathrm{a}$ \\
Untreated Control & $7.27 \mathrm{~b}$ & $6.53 \mathrm{~d}$ & $6.13 \mathrm{c}$ & $0.68 \mathrm{~b}$ & $1.27 \mathrm{c}$ & $1.77 \mathrm{~d}$ \\
\hline
\end{tabular}

Values in a column having same letter did not differ significantly $(\mathrm{P}=0.05)$ by LSD.

\subsection{Effect of Tricho-Compost, Trichoderma Inocula and Provax on Seedling Mortality of Barley}

Seedling mortality of barley was sharply reduced due to the soil amendment with Tricho-composts and seed treatment with Trichoderma inocula and Provax 200 WP during 201314, 2014-15 and 2015-16 cropping years (Table 3). The highest seedling mortality $31.67 \%, 46.67 \%$ and $50.00 \%$ in the first year, second year and third year, respectively was recorded in the untreated control plot. Lower seedling mortality range from $6.00-10.67 \%$ in first year, $16.67-21.67 \%$ in second year and $16.33-27.00 \%$ in the third year was recorded due to the soil amendment with Tricho-composts and seed treatment with Provax $200 \mathrm{WP}$ and Trichoderma inocula. The reduction of seedling mortality was range from $66.31-81.05 \%$ in first year, $53.57-64.28 \%$ in second year and $46.00-67.34 \%$ in third years due to different treatments as compared to untreated control. Soil amendment with Trichocompost-1 gave the highest reduction of seedling mortality followed by Tricho-compost-1, seed treatment with Provax $200 \mathrm{WP}$ and Trichoderma inocula compared to control.

Table 3. Effect of T. harzianum on the reduction of barley seedling mortality under Sclerotium rolfsii inoculated field soils during three consecutive years.

\begin{tabular}{|c|c|c|c|c|c|c|}
\hline \multirow[t]{2}{*}{ Treatments } & \multicolumn{3}{|c|}{ Seedling mortality during three consecutive years (\%) } & \multicolumn{3}{|c|}{$\begin{array}{l}\text { Reduction of seedling mortality } \\
\text { over control }(\%)\end{array}$} \\
\hline & 2013-14 & 2014-15 & 2015-16 & 2013-14 & 2014-15 & 2015-16 \\
\hline Seed treatment with Provax & 9.00 bc (17.39) & $18.33 \mathrm{~b}(25.31)$ & 20.67 bc $(26.92)$ & 71.58 & 60.72 & 58.66 \\
\hline Seed treatment with Trichoderma inocula-1 & $10.33 \mathrm{bc}(18.36)$ & $21.67 \mathrm{~b}(27.60)$ & $27.00 \mathrm{~b}(31.19)$ & 67.38 & 53.57 & 46.00 \\
\hline Seed treatment with Trichoderma inocula-2 & $10.67 \mathrm{~b}(19.04)$ & $18.33 \mathrm{~b}(25.31)$ & $23.00 \mathrm{bc}(28.63)$ & 66.31 & 60.72 & 54.00 \\
\hline Soil amendment with Tricho-compost-1 & $6.00 \mathrm{c}(13.91)$ & $16.67 \mathrm{~b}(24.05)$ & $16.33 \mathrm{c}(23.82)$ & 81.05 & 64.28 & 67.34 \\
\hline Soil amendment with Tricho-compost-2 & $6.67 \mathrm{bc}(14.95)$ & $16.67 \mathrm{~b}(24.05)$ & $16.67 \mathrm{~b}(24.05)$ & 78.94 & 64.28 & 66.66 \\
\hline Untreated Control & $31.67 \mathrm{a}(34.23)$ & $46.67 \mathrm{a}(43.09$ & $50.00 \mathrm{a}(45.00)$ & - & - & - \\
\hline
\end{tabular}

Values in a column having same letter did not differ significantly $(\mathrm{P}=0.05)$ by LSD; values within the parentheses were the Arcsine Transformed value

\subsection{Effect of Tricho-Compost, Trichoderma Inocula and Provax on the Yield of Barley}

The yield of barley was significantly increased by soil amendments and seed treatment with different formulation $T$. harzianum and Provax 200 WP (Table 4). The yield of barley was ranged from 2.50 to 2.95 tha $^{-1}$ in the first year, 2.23 to 2.77 tha $^{-1}$ in the second year and 2.16 to 2.93 tha $^{-1}$ in the third year due to application different treatments. Among the treatments, soil amendment with Tricho-compost-2 gave the highest yield of 2.95 tha $^{-1}$ in the first year, 2.77 tha $^{-1}$ in the second year followed by soil amendment with Tricho-compost-1, seed treatment with Provax 200 WP, seed treatment with Tricho-inocula-1 and Tricho-inocula-2. But in the third year Tricho-compost-1 and Tricho-compost-2 gave the higher yield of barley which was obtained from treatments followed by seed treatment with Provax 200 WP, Tricho-inocula-1 and Tricho-inocula-2. The lowest yield of barley was recorded from the untreated control plot by 1.62 tha $^{-1}, 1.61$ tha $^{-1}$ and 1.64 tha $^{-1}$ in the first year, second year and third year, respectively. Results showed that soil amendment with Tricho-composts, seed treatment with Trichoderma inocula and Provax 200 WP were sharply increased the yield of barley ranging from $35.20-45.08 \%, 27.80$ $41.88 \%$ and $24.07-44.03 \%$ in the $1^{\text {st }}$ year, $2^{\text {nd }}$ year and $3^{\text {rd }}$ year, respectively (Table 4). Therefore, considering the reduction of seedling mortality and enhancing plant growth as well as yield of barley, the effect of Tricho-composts were seemed to be superior over Tricho-inocula and Provax-200WP.

Table 4. Effect of T. harzianum on the yield of barley under Sclerotium rolfsii inoculated field soils during three consecutive years.

\begin{tabular}{|c|c|c|c|c|c|c|}
\hline \multirow{2}{*}{ Treatments } & \multicolumn{3}{|c|}{ Barley yield during three consecutive years $\left(\right.$ tha $\left.^{-1}\right)$} & \multicolumn{3}{|c|}{ Yield increased over control (\%) } \\
\hline & 2013-14 & 2014-15 & 2015-16 & 2013-14 & 2014-15 & 2015-16 \\
\hline Seed treatment with Provax & $2.58 \mathrm{ab}$ & $2.44 \mathrm{bc}$ & $2.32 \mathrm{~b}$ & 37.21 & 34.02 & 29.31 \\
\hline Seed treatment with Trichoderma inocula-1 & $2.50 \mathrm{~b}$ & $2.29 \mathrm{c}$ & $2.16 \mathrm{~b}$ & 35.20 & 29.69 & 24.07 \\
\hline Seed treatment with Trichoderma inocula-2 & $2.50 \mathrm{~b}$ & $2.23 \mathrm{c}$ & $2.16 \mathrm{~b}$ & 35.20 & 27.80 & 24.07 \\
\hline Soil amendment with Tricho-compost-1 & $2.75 \mathrm{ab}$ & $2.62 \mathrm{ab}$ & $2.93 \mathrm{a}$ & 41.09 & 38.55 & 44.03 \\
\hline
\end{tabular}




\begin{tabular}{|c|c|c|c|c|c|c|}
\hline \multirow{2}{*}{ Treatments } & \multicolumn{3}{|c|}{ Barley yield during three consecutive years $\left(\right.$ tha $\left.^{-1}\right)$} & \multicolumn{3}{|c|}{ Yield increased over control (\%) } \\
\hline & 2013-14 & 2014-15 & 2015-16 & 2013-14 & 2014-15 & 2015-16 \\
\hline Soil amendment with Tricho-compost-2 & $2.95 \mathrm{a}$ & $2.77 \mathrm{a}$ & $2.87 \mathrm{a}$ & 45.08 & 41.88 & 42.86 \\
\hline Untreated Control & $1.62 \mathrm{c}$ & $1.61 \mathrm{~d}$ & $1.64 \mathrm{c}$ & - & - & - \\
\hline
\end{tabular}

Values in a column having same letter did not differ significantly ( $\mathrm{P}=0.05)$ by LSD.

\section{Discussion}

The saprophytic fungus Trichoderma are naturally available in almost all agricultural soils and have been studied because of their bio-control potentiality against plant pathogenic fungi causing diseases of many crops, particularly many soil borne pathogens [27-29]. The soil borne plant pathogenic fungi especially $S$. rolfsii causing seedling disease of many crops is a widespread problem and the use of chemicals is hardly successful. Results from this study revealed that $T$. harzianum mass cultured on compost materials are effective for the management of seedling disease of barley caused by soil borne pathogen $S$. rolfsii. Several workers reported antagonistic activity of Trichoderma spp. against plant pathogenic fungi, particularly many common soil borne pathogens [27-29].

Synthetic media are costly for mass production of $T$. harzianum. Therefore cost effective organic substrates such as rice bran, wheat bran and their integration with mustard oilcake were used for mass production of $T$. harzianum and it is useful for large scale production of $T$. harzianum based composts for soil amendment. Rini and Sulochana [30] reported that locally available organic media viz., coir pith, cow dung, poultry manure and neem cake are the excellent sources of nutrition of antagonistic fungi like T. harzianum and $T$. viride. Besides, cow dung and neem cake mixture was reported as a recommended practice for field multiplication of Trichoderma [31].

In this study soil amendments with Tricho-composts and seed treatment with Trichoderma inocula and Provax 200 WP were found effective against seedling diseases of barley caused by soil borne pathogen $S$. rolfsii. The findings of Yaqub and shahzad [7], Ashrafizadeh et. al. [27], Uzun [32] and Younis [33] also indicated that Trichoderma isolates potentially reduced the disease caused by phtyopathogenic fungi such as $R$. solani, F. oxysporum and $S$. rolfsii. Different mechanism are said to be involved i.e. competition, production of antibiotics, inhibiting fungal growth by producing volatile and non-volatile compounds as reported by Calistru et al. [34] and Harman [35]. On the other hand several researchers also reported that application of Trichoderma resulted in higher shoot height, root length, and shoot weight of vegetable seedlings [36-38]. Thus it was revealed from the investigation that soil amendment with Tricho-compost was most effective option for reducing seedling mortality and increasing plant growth as well as getting higher yield of barley. The other options were seed treatment with chemical fungicide Provax-200WP or Trichoderma inocula for reducing seedling mortality and higher yield of barley. This finding is also supported by many researchers [39-40]. Therefore, it may be concluded that soil amendment with Tricho-compost is the best treatment followed by seed treatment with chemical fungicide Provax and seed treatment with Trichoderma inocula for reducing seedling disease caused by $S$. rolfsii and increasing plant growth and yield of barley.

\section{Conclusion}

Seedling disease of barley caused by soil borne pathogen Sclerotium rolfsii is one of the most common and prevalent disease which affects seed germination and seedling survival in the field. In this study the formulated bio-control agent Trichoderma harzianum based Tricho-compost, Trichoderma spore suspension and chemical fungicide Provax $200 \mathrm{WP}$ were tested against the disease in the field. The findings of the present investigations revealed that the formulated $T$. harzianum based Tricho-compost, Trichoderma inocula and chemical fungicide Provax 200 WP significantly reduced seedling mortality of barley in all the years. The yield of barley was sharply increased due to the T. harzianum formulations and Provax 200 WP compared to control. Among the treatments, application of Tricho-compost in soil was found more efficient in the reduction of seedling mortality and acceleration of plant growth with increased yield of barley under $S$. rolfsii inoculated field experiments in Bangladesh. Seed treatment with Provax $200 \mathrm{WP}$ and Trichoderma inocula also found promising in reduction of seedling mortality and increasing plant growth and yield of barley.

\section{Conflict of Interest Statement}

The authors declare that they have no competing interests with any financial interest (such as honoraria; educational grants; participation in speakers' bureaus; membership, employment, consultancies, stock ownership, or other equity interest; and expert testimony or patent-licensing arrangements), or non-financial interest (such as personal or professional relationships, affiliations, knowledge or beliefs) in the subject matter or materials discussed in this manuscript.

\section{References}

[1] Alam, A. K. M. M., Naher, N., Begum, M. 2006. Genetic diversity of some quantitative characters in hull-less barley. Bangladesh J. Agril. Res. 31 (3): 347-35

[2] Sharma, A., Yadav, M. 2013. Isolation and characterization of vesicular arbuscular mycroohiza from barley fields of jaipur district. International Journal of Agricultural Science and Research 3: 151-156. 
[3] Sharma, R. C., Duveiller, E. 2006. Spot blotch continues to cause substantial grain yield reductions under resource-limited farming conditions. Journal of Phytopathology 154, 482-488.

[4] Alam, K. B., Saha, N. K. 1991. Helminthosporium leaf blight of wheat- a new problem of Bangladesh. A paper presented at the CIMMYT regional workshop on Helminthosporium leaf blight, December 2-3, 1991, Kathmandu, Nepal. 12p.

[5] Shahjahan, A. K. M. 1993. Practical approaches to crop pest and disease management in Bangladesh. Bangladesh Agricultural Research Council. 168p.

[6] Gerhardson, B. 2002. Biological substitute for pesticides. Trends Biotechnology. 20: 338-343.

[7] Yaqub, F, Shahzad, S. 2008. Effect of seed pelleting with Trichoderma spp., and Gliocladium virens on growth and colonization of roots of sunflower and mugbean by Sclerotium rolfsii. Pak. J. Bot., 40: 947-963.

[8] Naher, L., Yusuf, K. U., Ismail, A., Hossain, K. 2014. Trichoderma spp.: A biocontrol agent for sustainable management of plant diseases. Pak. J. Bot., 46 (4): 1489-1493.

[9] Harman, G. E. 2011. Multifunctional fungal plant symbionts: new tools to enhance plant growth and Productivity. New Phytologist Commentry, Forum (3): 647-649.

[10] Singh, B. N., Singh, A., Singh, S. P., Singh, H. B. 2011. Trichoderma harzianum-mediated reprogramming of oxidative stress response in root apoplast of sunflower enhances defense against Rhizoctonia solani. European Journal of Plant Pathology 131 (1): 121-134.

[11] Benitez, T., Rincon, A. M., Limon, M. C., Codon, A. C. 2004. Biocontrol mechanisms of Trichoderma strains, a review article. Intl. Microbiol. 7: 249-260.

[12] Singh, H. B. (2006). Trichoderma: A boon for biopesticides industry. J. Mycol Pl Pathol. 36 (3): 373-384.

[13] Goes, L. B., Lima da Costa, A. B., Freire, L. L. C., Oliveria, N. T. 2002. Randomly Amplified Polymorphic DNA of Trichoderma Isolates and Antagonism Against Rhizoctonia solani. Braz. arch.biol.technol., 45 (2): 254-257.

[14] Kucuk, C., Kivanc, M. 2004. In vitro antifungal activity of strains of Trichoderma harzianum. Turk. J. Biol. 28: 111-115.

[15] Shalini, K. P., Lata, N., Kotasthane, A. S. 2006. Genetic relatedness among Trichoderma isolates inhibiting a pathogenic fungi Rhizoctonia solani, African Journal of Biotechnology, 5 (8): 580-584.

[16] Hasan, M. M., Alam, S. 2007. Efficacy of Trichoderma harzianum treated seeds on field emergence, seedling disease, leaf blight severity and yield of wheat cv. Gourab and Shourav under field condition. Intl. J. Boi-Res., 3 (6): 23-30.

[17] Vann, S. 2011. University of Arkansas, Division of Agriculture, Cooperative Extension Service, USA. http: //www.uaex.edu.

[18] Whipps, J. M., Lumsden, R. D. 2001. Commercial use of fungi as plant disease biological control agents: Status and prospects. Pages 9-22 in: Fungi as Biocontrol Agents: Progress, Problems and Potential. T. M. Butt, C. Jackson, and N. Magan, eds. CABI Publishing, Wallingford, UK.

[19] Harman, G. E., Howell, C. R., Viterbo, A., Chet, I., Lorito, M. 2004. Trichoderma species opportunistic, avirulent plant symbionts. Nat Review Microbiol. 2 (1): 43-56.
[20] Singh, A., Srivastava, S., Singh, H. B. 2007. Effect of substrates on the growth and shelf life of Trichoderma harzianum and its use in biocontrol of diseases. Bioresource Technol. 98: 470-473.

[21] Rettinassabababy, C., Ramadoss, N. 2000. Effect of different substrates on the growth and sporulation of Trichoderma viride native isolates. Agril. Sci. Digest. 20 (3): 150-152.

[22] Cotxarrera, L., Trillas-Gay, M. I., Steinberg, C., Alabouvette, C. 2002. Use of sewage sludge compost and Trichoderma asperellum isolates to suppress Fusarium wilt of tomato. Soil Biology and Biochemistry, 34: 467-476.

[23] Shamsuzzaman, S. M., Islam, A., Hossain, I. 2003. Trichoderma culture and germination of sweet gourd seed. Bangladesh J. Seed Sci. and Tech. 7 (1 \& 2): 91-95.

[24] Baxter, A. P., Rong, I. H., Roux, C., Van der Linde, E. J. 1999. Collecting and Preserving Fungi-A Manual for Mycology. Plant Protection Research Institute. Private Bag X134, Pretoria, 0001 South Africa.

[25] Barnett, H. L., Hunter, B. B. 1972. Illustrated Genera of Imperfect Fungi. 3rd Ed. Burges Co., Minneapolis, USA.

[26] Booth, C. 1971. The Genus Fusarium. Commonwealth Mycology Institute Kew, Survey, England.

[27] Ashrafizadeh, A., Etebarian, H. R. Zamanizadeh, H. R., 2005. Evaluation of Trichoderma isolates for biocontrol of Fusarium wilt of melon. Iranian J. Phytopathol. 41: 39-57.

[28] Freeman, S., Minz, D., Kolesnik, I., Barbul, O., Zreibil, A., Maymon, M., Nitzani, Y., Kirshner, B., Rav-David, D., Bilu, A., Dag, A., Shafir, S., Elad, Y. 2004. Trichoderma biocontrol of Colletotrichum acutatum and Botrytis cinerea, and survival in strawberry. Eur. J. Plant Pathol. 110: 361-370.

[29] Dubey, S. C., Suresh, M., Singh, B. 2007. Evaluation of Trichoderma species against Fusarium oxysporum fsp. Ciceris for integrated management of chickpea wilt. Biol. Contr. 40: 118-127.

[30] Rini, C. R., Sulochana, K. K. 2007. Substrate evaluation for multiplication of Trichoderma spp. Journal of Tropical Agriculture 45 (1-2): 58-60.

[31] KAU. 2002. Package of Practices Recommendations: Crops. Twelfth edition. Directorate of Extension, Kerala Agricultural University, Thrissur, 278p.

[32] Uzun, I. 2004. Use of spent mushroom compost in sustainable fruit production. Journal of Fruit and Ornamental Plant Research. 12: 157-165.

[33] Younis, N. A. 2005. Mycoparasitism of Trichoderma harzianum and Trichoderma longibrachiatum on Fusarium oxysporum f.sp. phaseoli the causal of bean wilt disease. Bull. Faculty Agric. Cairo Univ. 56: 201-219.

[34] Calistru, C., Mclean, M., Berjak, P. 1997. In-vitro studies on the potential for biological control of Aspergillus flavus and Fusarium moniliforme by Trichoderma species; A study of the production of extracelluar metabolites by Trichoderma species. Mycopathologia, 137 (20): 115-124.

[35] Harman, G. E. 2006. Overview of mechanisms and uses of Trichoderma spp. Phytopathol. 96: 190-194.

[36] Hossain, I., Shamsuzzaman, S. M. 2003. Developing Trichoderma based bio-fungicide using agro-waste. BAU Res. Prog. 14: 49-50. 
[37] Hossain, I., Naznin, M. H. A. 2005. BAU biofungicide in controlling seedling disease of some summer vegetables. BAU Res. Progr. 15: 32-35.

[38] Shaban, W. I., El-Bramawy, M. A. 2011. Impact of dual inoculation with Rhizobium and Trichoderma on damping off, root rot diseases and plant growth parameters of some legumes field crop under greenhouse conditions. Int. Res. J. Agric. Sci. Soil Sci. 1: 98-108.
[39] Hannan, M. A., Hasan, M. M., Hossain, I., Rahman, S. M. E., Ismail, A. M., Deog-Hwan, Oh. 2012. Integrated Management of Foot Rot of Lentil Using Biocontrol Agents under Field Condition. J. Microbiol. Biotechnol. 22 (7): 883-888.

[40] Devi, H. J., Maity, T. K., Paria, N. C. 2003. Effect of different sources of nitrogen on yield and economics of cabbage. Environ. Ecol. 21: 878-880. 